\title{
TERJADINYA OVERFLOW LUBRICATING OIL PADA LO PURIFIER
}

\author{
Dwi Prasetyo
}

Dosen Program Studi Teknika PIP Semarang

\begin{abstract}
ABSTRAK
Purifier pada dasarnya adalah sebuah bowl atau wadah silinder yang berputar dengan kecepatan tinggi. Ketika campuran minyak, air dan endapan lumpur masuk kedalam putaran cepat centrifugal purifier, endapan akan terlempar ke lapisan luar, air masuk pada lapisan tengah dan minyak pada lapisan paling dalam. Air yang telah dipisahkan akan keluar melalui laluan air keluar dan oli keluar melalui outletnya. Minyak lumas akan menjadi tidak layak digunakan apabila bercampur dengan air, pasir atau kerikil yang halus, lumpur, serta kotoran lainnya. Maka dari itu minyak lumas harus selalu dijaga supaya bebas dari kotoran semaksimal mungkin, maka dari itu harus dilakukan pembersihan pada minyak lumas. Tujuan dari penelitian ini yaitu untuk mengetahui penyebab terjadinya overflow lubricating oil pada purifier. Sedangkan tujuan khususnya adalah untuk mengetahui bagaimana metode SHEL digunakan dalam mencegah terjadinya overflow lubricating oil pada purifier.

Penelitian ini bersifat kualitatif dengan melakukan wawancara dan observasi langsung kelapangan untuk mengetahui penyebab terjadinya overflow lubricating oil pada purifier bersama para Masinis dan engine crew. Dari hasil identifikasi, ternyata peneliti menemukan bahwa main seal ring pada lubricaring oil purifier telah mengalami kerusakan, yang pada umumnya dalam keadaan normal dapat menutup celah antara bowl body dan bowl hood tidak lagi menutup rapat sehingga oli bersih keluar ke sludge port. Selanjutnya untuk Masinis ataupun crew mesin yang sedang tugas jaga harus selalu melakukan pengecekan terhadap suhu pada lubricating purifier dan juga harus melakukan maintenance sesuai dengan jam kerja. Sehingga nantinya tidak terjadi overflow lubricating oil pada purifier lagi, operasional mesin induk juga lancar dan tidak merugikan berbagai pihak.
\end{abstract}

Keywords : identifikasi, overflow lubricating oil, metode SHEL

\section{PENDAHULUAN}

\section{A. Latar Belakang}

Dalam melaksanakan praktek laut di kapal MT. Sophie Schulte, peneliti menyadari bahwa kondisi minyak lumas perlu dijaga kebersihannya agar dalam pemakaiannya tidak mempengaruhi daya kerja dari mesin induk. Untuk menghindari terjadinya gangguan proses pelumasan pada mesin, maka perlu diadakan suatu sistem pembersihan pada minyak pelumas. Agar mesin induk yang merupakan mesin penggerak utama dari sebuah kapal dapat bekerja secara optimal. Minyak lumas memegang peranan yang sangat penting dalam pengoperasian suatu mesin diesel. Minyak lumas akan menjadi tidak layak digunakan apabila bercampur dengan air, pasir atau kerikil yang halus, lumpur, serta kotoran lainnya. Maka dari itu minyak lumas harus selalu di jaga supaya bebas dari kotoran semaksimal mungkin, maka dari itu harus dilakukan pembersihan pada minyak lumas. 
Air dan partikel padat serta minyak yang berbeda berat jenisnya dapat dipisahkan dengan adanya gaya tarik bumi (gravity) yaitu dengan pengendapan. Namun cara tersebut membutuhkan waktu yang sangat lama. Tetapi dengan menggunakan gaya sentrifugal yang dihasilkan dengan putaran cepat, dimana gaya gravitasi digantikan dengan gaya sentrifugal akan menghasilkan gaya pemisahan yang ribuan kali lebih besar. Pemanfaatan gaya sentrifugal tersebut diterapkan dalam suatu pesawat bantu yang disebut purifier.

Menurut manual instruction book, purifier adalah permesinan bantu pemisah sentrifugal kecepatan tinggi yang dirancang khusus untuk melakukan proses memisahkan minyak lumas dari kotoran (sludge) maupun kandungan air sehingga minyak dapat dibersihkan dengan optimal, sebelum digunakan pada mesin. Purifier pada dasarnya adalah sebuah bowl atau wadah silinder yang berputar dengan kecepatan tinggi. Ketika campuran minyak, air dan endapan lumpur masuk ke dalam putaran cepat centrifugal purifier, endapan akan terlempar ke lapisan luar, air masuk pada lapisan tengah dan minyak pada lapisan paling dalam. Air yang telah dipisahkan akan keluar melalui laluan air keluar dan oli keluar melalui outletnya. Sebagaimana diketahui bahwa minyak lumas yang disuplai saat bunker masih kotor sehingga perlu dilakukan proses pembersihan (purifikasi). Namun pada kenyataannya kadang terjadi gangguan dan penyimpangan yang menyebabkan proses purifikasi tidak berjalan dengan baik (tidak normal).

Seperti yang terjadi pada waktu peneliti melaksanakan praktek laut, terjadi masalah pada lubricating oil purifier. Di mana saat itu kapal berlayar dari Kozmino ke China pada tanggal 15 Maret 2015. Waktu itu peneliti melakukan tugas jaga di kapal bersama dengan Masinis tiga pukul 08.00 12.00. Saat bertugas jaga terjadi alarm di engine control room dan di monitor tertulis L.O alarm failure. Setelah menganalisa ternyata terjadi overflow dalam purifier dimana minyak lumas tidak keluar melalui pipa outlet melainkan keluar melalui sludge port (overflow) menuju got. Sehingga menyebabkan kerugian dari segi materi, perusahaan harus mensuplai lebih banyak minyak lumas untuk kebutuhan di atas kapal. Dan perusahaan juga harus melakukan pembelian spare part guna perawatan purifier tersebut. Selain itu Masinis yang bertanggung jawab yang berhubungan dengan purifier mengalami kerugian dari segi waktu dan tenaga karena pada saat terjadi overflow yang bertugas jaga adalah Masinis tiga sedangkan yang bertanggung jawab adalah Masinis satu sehingga Masinis satu harus meluangkan waktu istirahatnya untuk turun ke kamar mesin untuk mengecek kondisi dari kelayakan purifier tersebut.

Berikut peneliti dan Masinis menemukan penyebab terjadinya overflow pada purifier adalah:

1. Ausnya main seal ring

2. Macetnya pilot valve

Walaupun terlihat sederhana, apabila diacuhkan dapat menyebabkan kerusakan dalam jangka waktu panjang jika tidak dicari solusinya. Banyak metode untuk mengidentifikasinya, salah satu metode untuk mengidentifikasi serta mencegah kerusakan atau penanganan gangguan pada permesinan adalah dengan memperhatikan prosedur, peralatan kerja, serta keselamatan dalam pengoperasian permesinan. Hal-hal tersebut dilakukan agar bahaya yang mungkin terjadi dapat dihindari serta mengetahui apa yang harus dilakukan jika bahaya atau kerusakan terjadi. Metode yang peneliti gunakan yaitu dengan metode S.H.E.L (Software, Hardware, Environment, Liveware). Metode SHEL adalah salah satu metode yang meliputi petunjuk, prosedur keselamatan, peralatan dan lebih menuju pada kesalahan manusia itu sendiri.

Dalam Standard Operational Procedure (SOP) tentang permasalahan Lubricating oil purifier dengan minyak lumas, banyak hal yang dapat diungkapkan dan dapat ditinjau serta dipandang dari berbagai aspek, apalagi bila dewasa ini di era modernisasi, ada 
beragam jenis purifier yang digunakan dengan sistem dan prinsip kerjanya masingmasing, dan dari pabrik yang berbeda-beda pula. Namun pada kenyataan sebenarnya dalam praktek sehari-hari, permasalahan yang dialami tentang perawatan Lubricating oil purifier tidaklah semudah apa yang dibayangkan, hal ini terbukti dari pengalaman peneliti, ABK maupun Masinis sendiri di atas kapal yang mengalami kendala dalam penanganan perawatan Lubricating oil purifier.

Kejadian ini sering terjadi sebagai gejala yang mendahului adanya kerusakan pada Lubricating oil purifier, keadaan ini bila tidak segera ditanggulangi akan menyebabkan pemakaian minyak lumas lebih boros dan akan berpengaruh pada kinerja motor induk. Motor induk akan mendapat pelumasan dengan mutu minyak luas yang rendah dan kerugian panas akibat gesekan bertambah besar, sehingga dikhawatirkan akan terjadi kerusakan yang serius dan bahkan bisa fatal pengaruhnya yang dapat menyebabkan terganggunya kelancaran operasional kapal.

Dengan mempertimbangkan kejadian dan kerugian yang ditimbulkan oleh Lubricating oil purifier akibat terjadinya overflow tersebut, maka peneliti tertarik melakukan penelitian untuk membuat penelitian dengan judul "Identifikasi terjadinya overflow lubricating oil pada L.O purifier di MT. Sophie Schulte dengan metode SHEL".

\section{B. Perumusan Masalah}

1. Mengapa terjadi overflow lubricating oil pada purifier?

2. Bagaimana mencegah terjadinya overflow dengan penerapan metode SHEL?

\section{Batasan Masalah}

Mengingat luasnya pembahasan masalah ini, maka penulis dalam melaksanakan pembahasan penelitian ini dibatasi dalam hal-hal berikut :

1. Penelitian dilaksanakan pada saat taruna melaksanakan praktek laut pada bulan September 2014 November 2015 di kapal MT. Sophie Schulte.

2. Penelitian meliputi penyebab dan cara mencegah terjadinya overflow dengan penerapan metode SHEL.

\section{Tujuan Penelitian}

Tujuan penelitian dari penelitian ini adalah sebagai berikut :

1. Untuk mengetahui penyebab terjadinya overflow lubricating oil pada purifier.

2. Untuk mengetahui bagaimana metode SHEL digunakan dalam mencegah terjadinya overflow lubricating oil pada purifier.

\section{KAJIAN PUSTAKA}

\section{A. Tinjauan Pustaka}

Landasan teori digunakan sebagai sumber teori yang dijadikan dasar dari pada penelitian. Sumber tersebut memberikan kerangka atau dasar untuk memahami latar belakang dari timbulnya permasalahan secara sistematis. Landasan teori juga penting untuk mengkaji dari penelitianpenelitian yang sudah ada mengenai masalah tekanan kompresi menggunakan metode SHEL. Oleh karena itu landasan teori ini, peneliti akan menjelaskan tentang konsep dasar teori SHEL, definisi dan tujuan SHEL dan pengertian proses dalam thermodinamika.

1. Konsep dasar teori SHEL

Konsep dasar dari teori SHEL adalah cara untuk mengidentifikasi masalah yang timbul dari suatu sistem dan mengoptimalkannya, dengan hubungan faktor manusia dan lingkungan (Reinhart:1996,). Konsep ini berasal dari 'SHEL MODEL' oleh Hawkins 1975, yang namanya berasal dari inisial komponennya adalah sebagai berikut software, hardware, environment, dan liveware.

2. Definisi dan tujuan SHEL 
"Central Liveware", liveware yang berada tengah dari SHEL, dapat didefinisikan sebagai unsur-unsur manusia seperti pengetahuan, sikap, budaya dan stres. Liveware ini dianggap sebagai inti dari SHEL dan komponen lainnya cocok dengan Liveware sebagai tokoh sentral (Hawkins, 1987)". Sistem L-H pada SHEL, interaksi antara Liveware dan Hardware (system L-H) biasanya bernama system manusia dan mesin.

L-S System di dalam SHEL, yang direpresentasikan sebagai interaksi antara Liveware dan Software. Sebagai Software menunjukkan benda-benda yang berwujud dari pada Hardware, jelas bahwa kesalahan interaksi L-S lebih sulit untuk memecahkannya daripada kesalahan interaksi L-H.

"Selain itu, antarmuka L-E ini yang bersangkutan pada organisasi, peraturan dan sosio-aspek lingkungan seperti moral karyawan dan kesehatan organisasi di bidang pelayaran. Hawkins (1987) terutama menekankan pada tiga faktor lingkungan: bising, panas dan getaran, yang dapat mengakibatkan kesalahan interaksi L-E.

L-L System antarmuka terakhir di SHEL, yang merupakan interaksi antara Liveware dan Liveware. Antarmuka L-L ini juga terkait dengan kepemimpinan, kerja sama crew dan interaksi kepribadian dan faktor manusia ahli telah dipastikan bahwa, masalah interaksi LL, seperti kesalahan dalam tim kerja, telah menyebabkan banyak kecelakaan.

3. Prinsip kerja purifier

Pemisahan terjadi di dalam bowl dimana minyak yang masih kotor masuk melalui inlet pipe. Minyak tersebut dibagi oleh distributor naik melalui saluran disc dan disalurkan kedalam disc stack. Minyak secara terus menerus mengalir ke arah tengah bowl dan dipisahkan dari air dan kotoran. Minyak bersih meninggalkan disc stack naik dan masuk ke dalam paring chamber.
Dari sini minyak bersih dipompa oleh pairing disc dan meninggalkan bowl melalui outletnya. Kotoran yang berupa lumpur menuju ke sludge space, dan air naik melewati bagian luar disc stack, melewati top disc terus ke bagian pinggir dari gravity disc dan meninggalkan bowl melalui water outlet dari purifier. Lumpur yang berkumpul di sludge space di bagian luar disc stack dan dikeluarkan secara bertahap melalui sludge port.

4. Faktor-faktor penyebab overflow minyak lumas pada saat pengoperasian purifier adalah :
a. Pengaruh gravity disc
b. Pemilihan gravity disc
c. Pemilihan gravity disc
d. Putaran tidak center

\section{B. Kerangka Berpikir}

Identifikasi terjadinya overflow lubricating oil pada L.O purifier di MT. Sophie Schulte

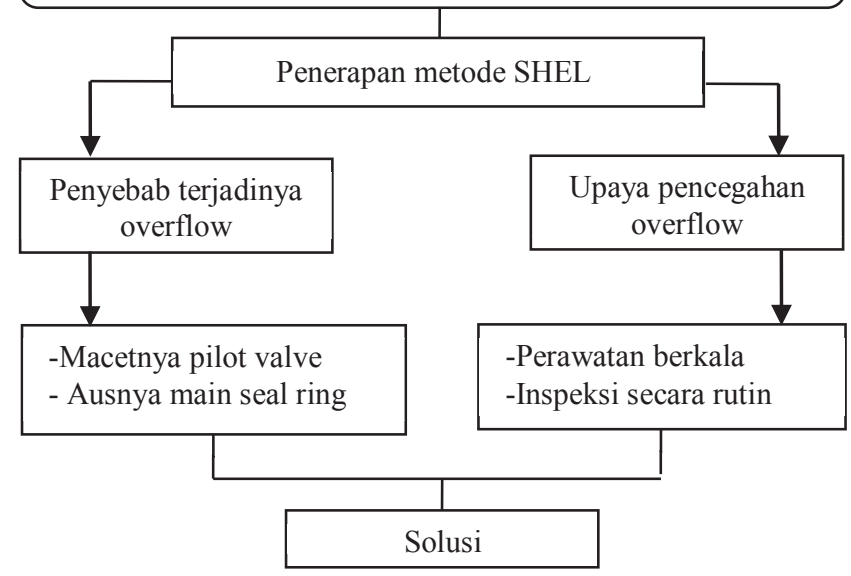

\section{Definisi Operasional}

Komponen pendukung proses purifikasi adalah :

1. Disc

2. Bowl body

3. Bowl nut

4. Bowl hood

5. Main seal ring

6. Distributor

7. Pilot valve

8. Gravity disc

9. Screw with hole

10. Sliding bowl bottom

11. Main cylinder

12. Sludge space 
13. Sludge port

14. Drain valve plug

15. Distributor

16. Drain channel

17. Oil paring chamber

18. Water paring chamber

19. Gear pump

\section{METODOLOGI}

\section{A. Metode Penelitian}

Penelitian pada hakikatnya merupakan suatu usaha untuk menemukan, mengembangkan dan menguji kebenaran suatu pengetahuan dengan menggunakan metode-metode ilmiah Pengumpulan dan analisis data menggunakan metode-metode ilmiah, baik yang bersifat kuantitatif dan kualitatif, eksperimental atau noneksperimental, interaktif atau non interaktif. Metode-metode tersebut telah dikembangkan secara intensif melalui berbagai uji coba sehingga telah memiliki prosedur yang baku.

Metode penelitian yang tepat dan benar semakin dirasakan urgensinya bagi keberhasilan suatu penelitian. Salah satu hal yang penting dalam setiap penelitian adalah perumusan metodologi penelitian. Melalui metodologi tergambar jelas cara penelitian tersebut dilaksanakan yang disusun dan tertata secara sistematis. Selain itu melalui metodologi dapat dilihat landasan teori tentang rancangan penelitian, model yang digunakan didahului dengan rancangan percobaan/penelitian eksperimen ataupun teknik-teknik yang digunakan dalam pengumpulan, pengolahan dan analisis data.

\section{B. Waktu dan Tempat Penelitian}

Waktu dan Lokasi penelitian yang diambil oleh peneliti untuk mengadakan observasi dan penelitian adalah di atas kapal MT. Sophie Schulte, disaat peneliti mengadakan praktek laut selama 1 tahun lebih, mulai bulan September 2014 sampai dengan bulan November 2015. Kapal ini berbendera Hongkong dan merupakan salah satu armada yang di milik perusahaan Bernhard Schulte Shipmanagement (BSM).

Adapun sumber data yang diperlukan dan dipergunakan dalam penyusunan penelitian ini merupakan informasi yang diperoleh penulis melalui pengamatan langsung dan wawancara Dari sumbersumber ini diperoleh data sebagai berikut :

\section{Data Primer}

Data primer adalah data yang diperoleh dari sumber pertama melalui prosedur dan teknik pengambilan data yang dapat berupa wawancara, observasi maupun penggunaan instrumen pengukuran yang khusus dirancang sesuai dengan tujuan. Data primer dalam penelitian ini berupa pengamatan peneliti selama praktek laut di atas kapal MT. Sophie Schulte tentang terjadinya overflow lubricating oil pada purifier dan wawancara langsung dengan engineer serta crew MT. Sophie Schulte.

2. Data Sekunder

Data Sekunder adalah data yang tidak langsung memberikan data kepada pengumpul data, misalnya lewat orang lain atau lewat dokumen. Pengumpulan data sekunder dalam penelitian ini melalui cara dengan cara membaca, mempelajari dan memahami melalui media lain yang bersumber dari literatur, buku-buku, serta dokumen perusahaan. Data ini diperoleh dari buku-buku yang berkaitan dengan obyek penelitian atau yang berhubungan dengan permasalahan yang akan dibahas, yang diperlukan sebagai pedoman dalam observasi. Data sekunder data yang diusahakan sendiri pengumpulannya oleh peneliti. Data ini diperoleh dari buku-buku referensi dan arsip-arsip kapal, media-media sosial serta buku-buku di perpustakaan yang berhubungan dengan permasalahan yang dibahas guna menunjang materi dalam penelitian.

\section{Metode Pengumpulan Data}

Metode pengumpulan data adalah teknik atau cara-cara yang dapat digunakan 
oleh peneliti untuk mengumpulkan data. Pengumpulan data dimaksudkan untuk memperoleh bahan-bahan yang relevan, akurat, dan nyata. Data-data tersebut diperoleh dengan cara: wawancara, observasi, dan kepustakaan. Masing-masing data memiliki kelebihan dan kekurangan sendiri-sendiri karena itu lebih baik mempergunakan suatu pengumpulan data lebih dari satu, sehingga dapat saling melengkapi satu sama lain untuk menuju kesempurnaan penelitian. Didalam penelitian ini peneliti menggunakan beberapa teknik pengumpulan data, antara lain :

\section{Observasi}

Observasi adalah suatu jenis metode yang dilakukan dengan cara pengambilan data dengan mengadakan pengamatan secara langsung terhadap masalah yang sedang diteliti. Teknik observasi digunakan dengan maksud untuk mendapatkan atau mengumpulkan data secara langsung selama melaksanakan praktek laut di atas kapal MT. Sophie Schulte, mengenai lubricating oil purifier untuk menghindari terjadinya overflow minyak lumas pada kegiatan tersebut.

2. Wawancara

Wawancara adalah percakapan yang dilakukan dua pihak, yaitu pewawancara yang mengajukan pertanyaan dan yang diwawancarai memberikan jawaban atas pertanyaan. Dalam penelitian ini, wawancara dilaksanakan setelah melakukan observasi saat peneliti melaksanakan praktek laut selama satu tahun. Wawancara dilakukan oleh peneliti itu sendiri, sedang yang diwawancarai melibatkan engineer kapal.

3. Dokumentasi dan kepustakaan

Teknik pengumpulan data melalui studi dokumentasi diartikan sebagai upaya untuk memperoleh data dan informasi berupa catatan tertulis/gambar yang tersimpan berkaitan dengan masalah yang diteliti. Cara mendapatkan atau mengumpulkan data dengan jalan mempelajari teori-teori dari hasil dokumen-dokumen kapal serta prosedur-prosedur yang berkaitan dengan pokok masalah yang diteliti. Untuk peraturan-peraturan yang berlaku, baik dalam ruang lingkup nasional maupun internasional.

\section{Teknik Analisis Data}

Dalam penulisan ini peneliti menggunakan metode analisis data, dengan cara menganalisa data-data yang diperoleh dari hasil penelitian. Selanjutnya peneliti membuat penyajian data yang merupakan penjabaran dari data-data yang diperoleh dari hasil penelitian sebelumnya yang telah disusun dengan urut sehingga diperoleh penyajian data yang mudah dipahami dan dimengerti oleh pembaca. Ada tiga macam metode analisis data yang digunakan pada penulisan ini, yaitu :

1. Data reduksi

Reduksi dapat didefinisikan sebagai proses pemilihan, pemusatan perhatian pada penyederhanaan, pengabstraksian dan transformasi data kasar yang muncul dari catatan-catatan tertulis di lapangan.

2. Data penyajian

Penyajian data merupakan sekumpulan informasi yang telah tersusun secara terpadu dan mudah dipahami yang memberikan kemungkinan adanya penarikan kesimpulan dan mengambil tindakan.

3. Mengambil kesimpulan

Mengambil kesimpulan merupakan kemampuan seorang peneliti dalam menyimpulkan berbagai temuan data yang diperolah selama proses penelitian yang ada di kapal dengan pelaksanaan yang benar sesuai buku petunjuk yang ada.

\section{PEMBAHASAN}

\section{A. Gambaran Umum Objek Yang Diteliti}

Name : Lubricating oil purifier

Model : SJ 20G (2 sets)

Max. Speed (Bowl) : $9512 \mathrm{r} / \mathrm{min}(50 \mathrm{~Hz})$

$9307 \mathrm{r} / \mathrm{min}(60 \mathrm{~Hz})$

Capacity : 1800 lit/h 
Max Temperature : $85^{\circ} \mathrm{C}$

Speed Motor Shaft : $1500 \mathrm{r} / \mathrm{min}$ (50

$\mathrm{Hz}$ ),

$1800 \mathrm{r} / \mathrm{min}(60 \mathrm{~Hz})$

Max. density of feed : $1100 \mathrm{~kg} / \mathrm{m}^{3}$

Maker : MISTSUBISHI

Sumber : manual book

\section{B. Hasil Penelitian}

Melalui pengamatan dan identifikasi pada seluruh sistem, maka peneliti mendapatkan hasil sebagai berikut :

1. Apa penyebab terjadinya overflow pada lubricating oil purifier.

Bekerjanya purifier dengan optimal apabila penggunaan dan perawatan dari purifier tersebut sesuai jam kerja dan sesuai dengan instruction manual book. Berdasarkan pengalaman yang dialami peneliti di kapal MT. Sophie Schulte, peneliti menemukan masalah yang berhubungan dengan purifier, yaitu terjadinya overflow pada L.O purifier, sehingga menimbulkan alarm di engine control room. Oleh karena itu perlu diadakan pengecekan serta perawatan terhadap komponen lubricating oil purifier.

Dugaan sementara penyebab terjadinya overflow tersebut akibat tidak normalnya komponen-komponen berikut:

1. Main seal ring

Main seal ring adalah sebuah perangkat purifier yang berfungsi untuk menutup celah antara bowl hood dengan main cylinder pada saat terjadinya proses pengoperasian purifier. Secara normal closing water dapat mendorong main cylinder ke atas untuk menutup sludge port. Jika main seal ring megalami kerusakan atau tidak berfungsi secara normal, maka bahan bakar akan keluar diantara bowl hood dengan main cylinder menuju ke saluran pembungan kotoran. Adapun penyebab rusaknya main seal ring yaitu: a. Faktor pemasangan

Pada saat pemasangan sebuah seal ring harus disertai dengan ketelitian dan teknik yang benar. Pemasangan dari seal ring yang terpasang rapat dan sebagian melintir itu akan mengakibatkan bowl body dengan main cylinder tersebut tidak rapat, sehingga minyak lumas yang belum sempat dipisahkan dengan air dan kotoran akan keluar melewati celah-celah antara bowl body dan main cylinder akibatnya minyak lumas yang masih bersih ikut keluar melalui sludge port atau overflow.

b. Faktor usia

Kerusakan pada seal ring bisa dipengaruhi oleh faktor usia sebab, komponen ini terbuat dari bahan karet yang lama kelamaan akan menjadi renggang dan bila sudah melewati batas kerja maksimum enam bulan secara otomatis sifatsifat mekanis yang akan ditimbulkan oleh seal ring akan berkurang dan mengakibatkan seal ring tidak lagi berfungsi sebagai perapat yang baik. Terkadang meskipun usia dari seal ring belum melewati dari batas maksimum tapi sudah mengalami kerusakan atau sudah tidak berfungsi dengan baik. Ini dikarenakan kualitas dan bahan dari seal ring kurang mempunyai mutu yang tinggi atau kurangnya perawatan secara rutin, maka pada saat pengopersian akan terjadi overflow. 


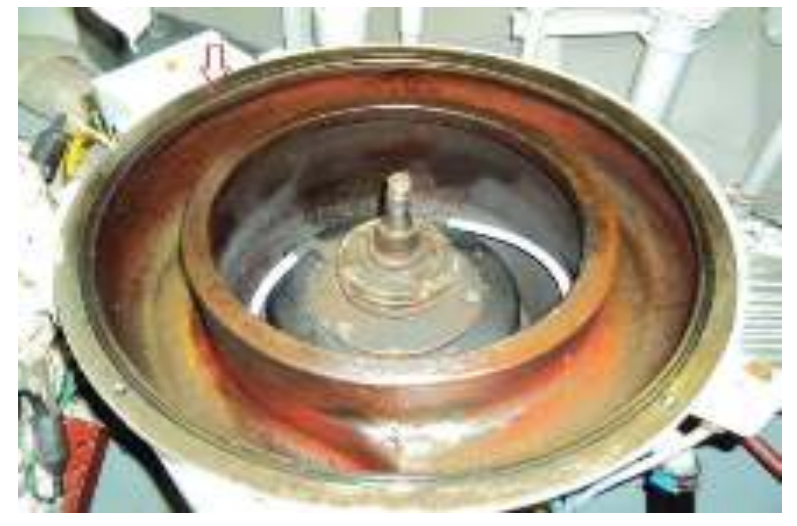

Gambar 1 : Main seal ring baru

2. Pada pilot valve

Katup bantu (pilot valve) sangat berperan penting dalam proses pembukaan dan penutupan bowl, karena alat ini menahan air tekanan rendah sehingga main cylinder dapat terangkat dan lubang pembuangan sludge dapat tertutup. Selama proses pembersihan minyak terjadi atau purifier dalam operasi normal. Pada saat proses blow up, air bertekanan tinggi dialirkan secara otomatis dan dapat pula dilakukan secara manual dengan menggunakan katup solenoid untuk menekan katup bantu pada bowl sehingga saluran pembuangan air bertekanan rendah terbuka dan air terpancar keluar mengakibatkan main cylinder akan turun serta lubang pembuangan sludge terbuka dan terpancar keluar.

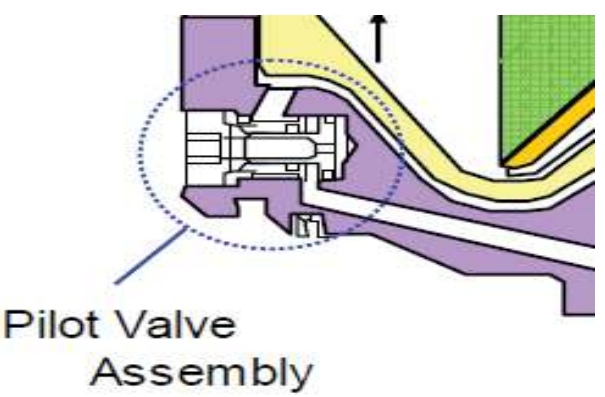

Gambar 2 : Letak posisi pilot valve pada purifier

Pada saat proses pembuangan air bertekanan rendah untuk menurunkan main silinder. Hal ini tidak dapat terjadi karena adanya kerak yang menempel pada pilot valve menyebabkan terjadinya kemacetan penutupan. Pilot valve tidak bisa menutup ruang tekan closing water sehingga closing water mengalir keluar dan mengkibatkan kebocoran. Kerak yang menghalangi pergerakan dari pilot valve berasal dari penggunaan air hasil dari penekan pada main cylinder pada saat beroperasi, air inilah yang mengandung zat kapur dan materi lainnya. Proses bertumpuknya kerak pada pilot valve sehingga menutupi ruang tekan closing water, akibatnya kebocoran terjadi karena closing water tidak mampu menekan main cylinder ke atas hal ini akan mengakibatkan tidak normalnya proses purifikasi L.O purifier dalam menghasilkan minyak lumas bersih sehingga minyak lumas yang didistribusikan menuju main engine masih dalam keadaan tidak bersih karena kebocoran tersebut. Dari hasil pengukuran yang Masinis dan peneliti lakukan, ternyata lubang pada pilot valve mengalami penyusutan yang disebabkan oleh kerak pada lubang pilot valve. Hal ini menyebabkan pilot valve tidak dapat menutup bowl, sehingga minyak lumas ikut keluar ke sludge tank.

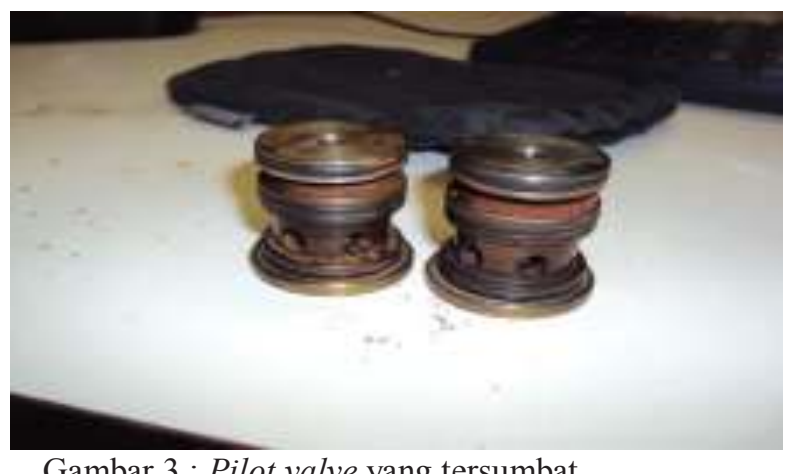

3. Pada pemasangan gravity disc

Gravity disc adalah suatu bidang pemisah antara minyak dan air dengan diameter dari bidang tersebut 
ditentukan oleh selisih dari kepekatan minyak dan air serta diameter dari lubang laluan keluar dari minyak dan air. Kemampuan purifier adalah memisahkan minyak dari air dan lumpur yang berada pada oli bersih . Ini sangat dipengaruhi oleh ukuran gravity disc. Hal ini bertujuan untuk mengatur cara pelemparan sehingga zat cair yang masuk, yang mempunyai berat jenis yang lebih berat akan terlempar jauh, sedangkan yang mempunyai berat jenis yang lebih ringan akan berada dekat pada pusat putaran.

Jika berat jenis dari minyak lumas yang masuk kedalam purifier berubah maka perbandingan garis tengah (diameter) harus diubah dan cincin tersebut adalah gravity disc. Agar cairan minyak dan air serta lumpur tidak bersatu atau tercampur kembali pada waktu air dan minyak keluar maka dipasang gravity disc. Namun sering kali ukuran ini kurang bahkan tidak diperhatikan sehingga penggunaannya kadang tidak tepat sesuai dengan penigkatan atau penurunan berat jenis minyak lumas, kelalaian tersebut dapat mengakibatkan proses pembersihan tidak sesuai yang diharapkan atau kurang baik Dari hasil pengamatan ternyata pemilihan gravity disc telah sesuai dengan petunjuk manual instruction book. Masinis dan peneliti menyimpulkan bahwa gravity disc bukanlah salah satu penyebab yang menyebabkan terjadinya overflow pada lubricating oil purifier.

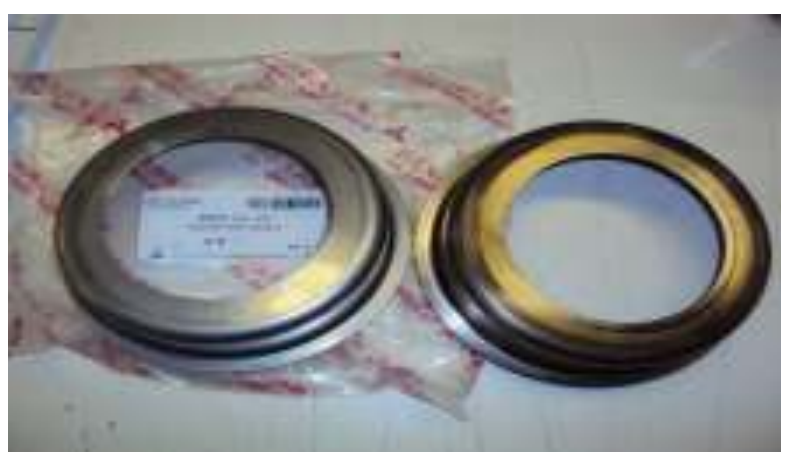

Gambar 4 : Gravity disc

\section{Putaran shaft}

Gagalnya purifier distart kembali setelah terjadi automatic stop disebabkan putarannya imbal (tidak senter) sehingga tidak mampu melampui batas kritis. Pertama kali putaranya jalan pelan-pelan namun semakin lama semakin cepat, untuk menuju putaran normal biasanya melalui putaran yang diiringi dengan getaran, getaran inilah yang dinamakan putaran kritis. Putaran purifier yang imbal (tidak senter) sulit bahkan tidak mungkin mencapai putaran normal, apabila putaran tidak normal maka daya atau tenaga untuk melempar dalam gaya centrifugal tidak tercapai sehingga bahan bakar dan air akan tercampur.

Pada saat lubricating oil purifier dijalankan ternyata putarannya dapat mencapai putaran normal dan dapat berjalan dengan lancar. Masinis dan peneliti menyimpulkan bahwa putaran bukanlah salah satu penyebab terjadinya overflow pada lubricating oil purifier.

5. Pada bowl disc

Pada dinding bagian dalam bowl banyak kotoran-kotoran yang menempel. Agar bowl disc tidak kotor sesuai yang dianjurkan oleh instruction manual book purifier dilakukan pembersihan setiap 3000 jam pada saat pencucian bowl (mangkuk), bowl hood (kap mangkuk), bowl body (badan mangkuk), dan bowl disc (piringan mangkuk) serta dapat diperiksa bagian-bagian lainnya seperti: O-ring packing atau seal ring. Bila pada bagian-bagian tersebut rusak maka harus segera diganti untuk mencegah kebocoran pada purifier tersebut. Setelah dibuka ternyata bowl disc dalam keadaan bersih dan tidak ada bagian bowl disc yang tersumbat. Masinis dan peneliti menyimpulkan 
bahwa bowl disc bukanlah salah satu penyebab terjadinya overflow pada lubricating oil purifier.

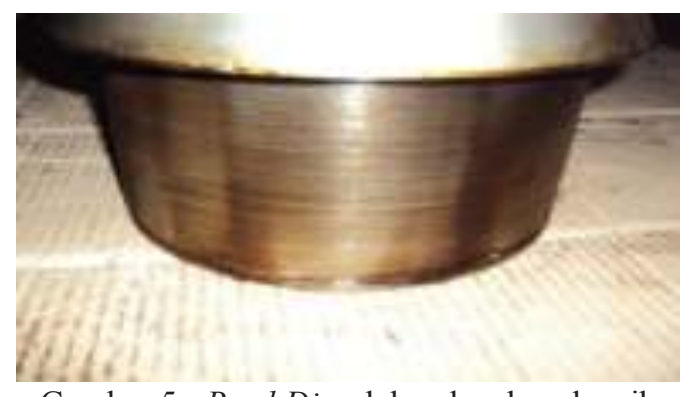

Gambar 5 : Bowl Disc dalam keadaan bersih

\section{Pembahasan masalah}

Pembahasan mengenai penyebab terjadinya overflow lubricating oil pada L.O purifier, peneliti paparkan dengan metode S.H.E.L.

\section{Software}

Sofware adalah bagian non-fisik system termasuk prosedur, manual dan aturanaturan dalam melakukan penanganan suatu pekerjaan. Di bawah ini adalah kelengkapan prosedur yang harus ada di atas kapal sehingga suatu pekerjaan akan berjalan dengan lancar. Standar prosedur kerja adalah sebagai berikut :

a. Standard operation procedure (SOP)

Agar memahami kegiatan dalam suatu pekerjaan dengan baik setiap organisasi harus memiliki suatu acuan, instruksi ataupun prosedur kerja. Karena dengan adanya prosedur atau acuan ini para crew, atasan, dan manajemen untuk mendapatkan suatu kejelasan serta kemudahan transparansi dalam setiap prosedur pelayanan yang diberikan.

b. Manual book

Manual book adalah buku panduan didalamnya terdapat suatu panduan informasi tentang bagaimana cara mengatasi suatu masalah dan spesifikasi sistem. Manual repair adalah buku panduan yang digunakan dalam memandu pelaksanaan perbaikan yang mengacu pada standar pabrik (maker). Dalam perawatan sistem pendinginan banyak yang tidak sesuai.

c. Instruksi kerja
Instruksi kerja adalah suatu perintah dan petunjuk-petunjuk yang bersumber pada peraturan dan kebijaksanaan dari pihak perusahaan. Instruksi kerja biasanya digunakan untuk penyelesaian masalah yang akan dikerjakan, sehingga instruksi ditujukan kepada banyak pihak untuk menyelesaikan hal tersebut.

Pada penyebab terjadinya overflow pada L.O purifier maka harus selalu memperhatikan instruction manual book yang sudah mencapai jam kerjanya (running hours), selalu melakukan pendataan dengan menjurnal dan mencatat semua pesawat yang ada alat ukur dan temperatur setiap bulan dimasukkan pada monthly report dan engine performance agar tekanan L.O yang menurun dapat diketahui, ini merupakan suatu usaha atau kegiatan agar tekanan L.O selalu dalam keadaan yang baik dan dapat dicegah terjadinya overflow.

\section{Hardware}

Hardware mengacu pada setiap komponen fisik dan non-manusia dari sistem purifikasi.

\section{a. Pada pilot valve}

Pilot valve dipergunakan untuk membuka dan menutup saluran air bertekanan yang dipergunakan untuk membuka dan menutup bowl. Apabila pilot valve ini mengalami gangguan maka akan berdampak pada bowl. Pilot valve tidak bisa menutup ruang tekan closing water sehingga closing water mengalir keluar dan mengakibatkan kebocoran sehingga proses purifikasi tidak berjalan optimal karena minyak lumas yang seharusnya masuk ke dalam service tank ikut terbawa menuju sludge tank. Akan tetapi dengan adanya kerak yang menempel pada pilot valve, menyebabkan terjadinya kemacetan penutupan. Pilot valve tidak bisa menutup ruang tekan closing water sehingga closing water mengalir keluar dan mengkibatkan kebocoran. Kerak yang menghalangi pergerakan dari pilot 
valve berasal dari penggunaan air hasil dari penekan pada main cylinder pada saat beroperasi, air inilah yang mengandung zat kapur dan materi lainnya.

Proses lengketnya/bertumpuknya kerak pada pilot valve sehingga menutupi ruang tekan closing water, akibatnya kebocoran terjadi karena closing water tidak mampu menekan main cylinder ke atas hal ini akan mengakibatkan tidak normalnya proses purifikasi lubricating oil purifier dalam menghasilkan minyak bersih. Kerakkerak yang menempel di pilot valve pada bowl body harus dibersihkan dengan cara melepaskan pilot valve pada bowl body rendam dengan larutan chemical pelunak kotoran agar memudahkan melepaskan kotoran yang menempel. Adapun dampak dari pada buntunya pilot valve adalah sebagai berikut :

1) Dengan buntunya pilot valve maka proses penutupan bowl tidak dapat berjalan dengan baik.

2) Dengan buntunya pilot valve maka air bertekanan rendah tidak akan bisa menutup bowl sehingga menyebabkan terjadinya overflow.

3) Main cylinder bottom tidak dapat terangkat atau terdorong $\mathrm{ke}$ atas untuk menutup sehingga dapat menyebabkan overflow.

\section{b. Pada main seal ring}

Fungsi dari main seal ring adalah sebagai perapat antara bowl hold dan main cylinder, di mana saat terjadi proses pemisahan di dalam bowl purifier, main seal ring akan menjaga agar minyak lumas, air, dan kotoran tidak ada yang bocor dan keluar melalui sisi kotoran atau sludge. Jika main seal ring mengalami kebocoran maka proses purifikasi tidak akan terjadi karena minyak bocor dan keluar melalui ke sisi sludge. Rusaknya main seal ring (keras dan tidak elastis) adalah juga merupakan salah satu faktor penyebab terjadinya overflow.

Main seal ring sudah tidak berfungsi sebagaimana mestinya karena lamanya pemakaian, maka tidak ada jalan lain kecuali main seal ring tersebut harus diganti dengan yang baru, pergantian seal ring tersebut harus sesuai dengan ukuran sebelumnya atau yang lama dengan mempunyai tipe yang sama. Hal ini juga dapat menghindari ketidakcocokan komponen dalam pemasangan pada main cylinder nantinya.

Terjadinya peluberan bahan bakar di sludge port disebabkan karena terjadinya kerusakan pada main seal ring sehingga bahan bakar keluar melalui celah antara bowl nut dengan katub slinder. Peluberan bahan bakar ini disebabkan karena faktor pemasangan yang kurang baik dan faktor usia. Adapun tindakan yang harus diambil untuk menghindari peluberan bahan bakar adalah sebagai berikut :

a) Faktor pemasangan

Pemasangan seal ring harus dengan teknik yang baik dan cara pemasangan yang benar yaitu :

1) Pemasangan seal ring harus dipasang hati-hati agar tidak melintir.

2) Dalam menggabungkan main seal cylinder pada bowl body, berikan minyak untuk menggeser sebagian komponen main cylinder permukaan penyegel tidak rusak, apabila main cylinder yang menyentuh ring sulit bergeser, lebih baik mengetuk luar dari bowl body dengan kayu.

3) Berikan silicon pada masingmasing bagian seal ring dengan rata agar kerapatan dapat terjaga serta kebocoran dapat terhindar.

b) Faktor usia

Apabila seal ring sudah tidak berfungsi sebagaimana mestinya karena lamanya pemakaian maka tidak ada 
jalan lain kecuali seal ring tersebut harus diganti dengan yang baru, pengantian seal ring tersebut harus sesuai dengan ukuran sebelumnya dan mempunyai tipe untuk purifier tersebut. Hal ini juga dapat menghindari ketidakcocokan komponen dalam pemasangan pada katub cylinder nantinya. Di dalam instruction manual book purifier mengatakan bahwa standar pemakaian main seal ring 3000 jam, lewat dari itu perubahan wujud bahan dan ukuran sudah berubah tidak sesuai dengan standar yang ditentukan.

3. Environment

Environment disini berdasarkan masalah yang ditimbulkan dari kondisi lingkungan yang berpengaruh terhadap purifier salah satunya adalah air tawar. Kualitas air tawar sangat berpengaruh terhadap terjadinya kerak pada pilot valve dan korosi pada pipa sehingga menyebabkan macet pada pilot valve.

Sesuai dengan kendala lingkungan yang dihadapi pada purifier dan pemecahan masalahnya. Kendala yang telah terjadi pada lingkungan di mana pemipaan pada purifier khususnya pada saluran air tawar mengalami korosi akibat kelembapan udara sekitar maka pencegahan korosi dapat dilakukan dengan cara mencegah kontak dengan oksigen dan air. Korosi pada pipa besi memerlukan oksigen dan air. Bila salah satu tidak ada, maka peristiwa korosi tidak dapat terjadi. Peristiwa korosi pada pipa merupakan fenomena yang tidak dapat dihindari, namun dapat dihambat maupun dikendalikan untuk mengurangi kerugian dan mencegah dampak negatif yang diakibatkannya. Dengan penanganan ini umur produktif saluran pipa pada sistem pendinginan mesin diesel generator menjadi panjang sesuai dengan yang direncanakan, bahkan dapat diperpanjang untuk memperoleh nilai ekonomi yang lebih tinggi. Upaya penanganan korosi diharapkan dapat banyak menghemat biaya operasional, sehingga berpengaruh terhadap efisiensi serta menghemat anggaran perawatan .

Korosi dapat dicegah dengan cara sebagai berikut :

a. Melapisi pipa dengan cat

Bertujuan untuk menghindarkan kontak dengan udara dan air. Cat yang mengandung timbel dan zink akan lebih baik, karena keduanya melindungi besi terhadap korosi.

b. Melapisi pipa dengan oli atau grease Bertujuan untuk mencegah kontak antara permukaan luar pipa dengan air sehingga proses korosi tidak terjadi.

c. Melapisi pipa dengan galvanis (pelapisan dengan Zink)

Pipa besi dilapisi dengan zink. Berbeda dengan timah, zink dapat melindungi pipa dari korosi sekalipun lapisannya tidak utuh. Hal ini terjadi karena suatu mekanisme yang disebut perlindungan katode. Oleh karena potensial reduksi pipa besi lebih positif dari pada zink, maka pipa yang kontak dengan zink akan membentuk sel elektrokimia dengan pipa sebagai katode. Dengan demikian pipa terlindungi dan tahan terhadap karat.

\section{Liveware}

Liveware mengacu pada setiap manusia dari system dalam aspek relasional, manajemen, pengawasan, interaksi dalam proses perawatan sistem pelumasan. Bahwa faktor manusia sebagai salah satu penyebab dan perlu penganalisaan lebih dalam, karena prasarana yang dimiliki di atas kapal jika tidak ditunjang dengan sumber daya manusia yang handal akan sia-sia. Faktor-faktor tersebut adalah sebagai berikut :

a. Faktor komunikasi yang buruk

Suatu tim kerja di atas kapal haruslah memiliki interaksi yang baik, karena itu komunikasi sangatlah penting dalam sebuah tim kerja agar memperoleh keberhasilan. Tim kerja yang solid adalah tim kerja yang selalu menjaga 
komunikasi antara individu yang satu dengan individu yang lainnya, sehingga menciptakan kerja tim menjadi lebih baik.

\section{b. Faktor stres}

Stres merupakan istilah umum yang diaplikasikan sebagai tekanan hidup yang sering dirasakan semua orang dalam hidupnya. Terjadinya stres di tempat kerja hampir tidak dapat dihindari dalam banyak jenis pekerjaan. Meskipun banyak definisi dan perdebatan tentang pengertian stres di tempat kerja, pada dasarnya bahwa stres adalah respons yang adaptif, dimensi oleh perbedaan-perbedaan individual, dan atau proses psikologis yang merupakan sebuah konsekuensi dari tindakan.

c. Faktor kelelahan kerja

Akibat logis dari suatu kelelahan adalah pekerjaan yang berat untuk diselesaikan, sehingga berdampak terhadap individu yang bersangkutan adalah penurunan kinerja. Semakin sering dan beratnya kelelahan yang dihadapi oleh crew menjadikan crew tidak memiliki semangat dalam melakukan pekerjaanya. Ujungnya adalah kinerjanya rendah dan cenderung jenis kelelahan akan berhubungan dengan jenis dan beban pekerjaan seseorang.

Sesuai dengan kendala-kendala yang terjadi pada sumber daya manusia, dan mengingat manusia sebagai sumber penggerak utama dalam perawatan purifier dalam hal ini khususnya terhadap sistem pelumasan yang sangat berperan penting terhadap kerja purifier, maka pemecahan masalahnya adalah sebagai berikut:

1) Komunikasi

Komunikasi antar crew harus terjaga dengan baik, kerja tim dalam melakukan perawatan diesel generator dalam hal ini khususnya sistem pendinginan diadakan komunikasi antar crew, hal ini dilakukan untuk memudahkan dan memperlancar keberhasilan perawatan dan perbaikan. Seperti yang kita ketahui sumber daya manusia merupakan yang paling mendasar dan paling utama mengingat manusia sebagai sumber penggerak utama dalam operasional kapal, oleh sebab itu komunikasi harus terjaga dengan baik di atas kapal, antar crew dengan crew lain, sebaiknya juga sebelum melakukan sering dan komunikasi sebelum melakukan pekerjaan, agar pekerjaan yang dikerjakan berjalan dengan lancar.

2) Mencegah fatique dan stres

Adapun untuk itu diperlukan langkah-langkah sistematis.

Berdasarkan volume dan bobot kelelahan kerja maka individu crew sebaiknya melakukan langkah-langkah sebagai berikut :

a) Mengetahui penyebab mengapa terjadi kelelahan kerja, kapan saja, dimana, dan ketika mengerjakan apa.

b) Kalau dirasa terlalu berat perlu melakukan konsultasi dengan orang yang ahli dan berpengalaman.

c) Melakukan pemulihan kelelahan dengan cara berolahraga secara teratur, tidur yang cukup, bersosialisasi, relaksasi, dan kalau dianggap perlu berobat ke dokter.

d) Mengambil hak cuti kerja.

\section{KESIMPULAN}

\section{A. Kesimpulan}

Berdasarkan hasil pengamatan dan identifikasi data yang telah dilakukan di atas kapal MT. Sophie Schulte peneliti menemukan permasalahan yaitu terjadinya overflow pada lubricating oil purifier. Peneliti dapat menyimpulkan bahwa yang dialami selama melakukan penelitian di atas kapal MT. Sophie Schulte sebagai berikut :

1. Setelah melakukan penelitian ternyata peneliti menemukan bahwa main seal ring pada lubricating oil purifier telah mengalami kerusakan, 
yang pada umumnya dalam keadaan normal dapat menutup celah antara bowl body dan bowl hood namun karena mengalami kerusakan, tidak dapat lagi menutup rapat sehingga oli bersih keluar ke sludge port.

2. Setelah pilot valve diukur ternyata diameter dalam yang pada keadaan normal $6 \mathrm{~mm}-7.5 \mathrm{~mm}$ telah mengalami penyempitan menjadi 4 mm yang diakibatkan kerak pada pilot valve tersebut, sehingga supply water yang berfungsi menutup bowl body tidak lagi bekerja dan mengakibatkan oli bersih ikut keluar ke sludge port.

\section{B. Saran}

Berdasarkan dari permasalahan yang sudah diuraikan dan diberikan solusi untuk pemecahannya, agar komponen mesin induk dapat bekerja dengan baik. Untuk itu peneliti akan memaparkan saran-sarannya sebagai berikut :

1. Sebaiknya Masinis ataupun crew mesin yang sedang tugas jaga harus selalu melakukan pengecekan terhadap suhu pada lubricating purifier dan juga harus melakukan maintenance sesuai dengan jam kerja.

2. Sebaiknya filter air tawar yang berada pada sistem lubricating oil purifier sering dibersihkan untuk mencegah menumpuknya kerak yang terdapat pada pilot valve.

\section{DAFTAR PUSTAKA}

Alan JS, Carl DH, John JG. 2008. Safety Management Systems in Aviation. USA : Ashgate Publishing Company

Cadet Handouts Course Bernhard Schulte Shipmanagement

Roader, Catalin. 2005. Dry Docking Specification. Bernhard Schulte Shipmanagement. Cyprus
Taylor, D.A. 2002. Introduction to marine Engineering (Revised Second Edition). Great Britain : Athenaeum Press Ltd

Hadi, Sutrisno. 2010. Metodologi Research. Yogyakarta : Andi Offset

Jackson, Leslie, and Thomas D. Morton. 2001. General Engineering Knowledge For Marine Engineers. Great Britain : Thomas Reed Publications

Manual Instruction Book. 2005. Mitshubishi Selfjector, Mitsubishi Kakoki Kaisha

Indrawan, Rully dan Poppy Yaniawati. 2014. Metodologi Penelitian. Bandung: PT. Refika Aditama

Sugiyono. 2010. Metode Penelitian Kuantitatif Kualitatif dan $R \& D$. Bandung : Alfabeta

http://wikiofscience.wikidot.com/technology :shell-model-of-human-factors

http://mrosafety.blogspot.co.id/2012/08/shel 1-model.html 